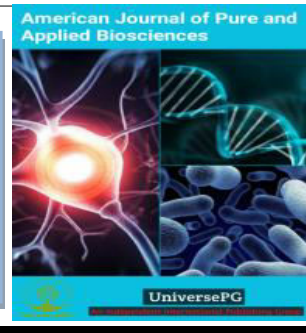

\title{
Socioeconomic Factors of Forest Dependency in Developing Countries: Lessons Learned from the Bandarban Hill District of Bangladesh
}

\author{
Morgubatul Jannat ${ }^{1 *}$, Mohammed Kamal Hossain ${ }^{1}$, and Mohammad Main Uddin ${ }^{1 \& 2}$ \\ ${ }^{1}$ Institute of Forestry and Environmental Sciences, University of Chittagong, Chittagong - 4331, Bangladesh; ${ }^{2}$ School of \\ Biological Sciences, The University of Queensland, QLD-4072, Australia. \\ *Correspondence: mjruhin@cu.ac.bd
}

\begin{abstract}
Forests provide direct and indirect economic benefits to forest dependent communities in the world, especially in the developing countries contributing to the national economy. The present study aims with the socioeconomic status and factors favoring forest conservation and influencing people's dependency on forest resources in the Bandarban hill district of Bangladesh. The study was based on Focus Group Discussion (FGD) and socioeconomic survey through semi-structured questionnaire. The study revealed that peoples' income from forest and forest-related occupations were positively related to their forest dependency. However, respondent's education level significantly reduced their dependency on forest resources. Thus, educating the forest-dependent people and supporting alternative livelihoods may be an option for effective forest management and conservation. This study represents an important pioneer step in taking a holistic view of the peoples' dependency on forest resources which might be helpful for policymakers in future to ensure sustainable forest management and conservation in developing countries like Bangladesh.
\end{abstract}

Keywords: Forest dependency, Forest income, Livelihoods, Bandarban, FGD, and Socio-economic factors.

\section{INTRODUCTION}

People's dependency on forest resources is a multidimensional phenomenon due to the evidence that forests give diversified benefits to humans being. The total forest area of Bangladesh is about 2.53 million hectares (Hossain, 2016; Hossain, 2015) of which $84 \%$ has been classified as natural forest and $16 \%$ as plantation forest (Hossain and Hoque, 2013; Rahman et al., 2010). Bangladesh occupies diversified forest types (FMP, 2016) ranging from wetlands, evergreen, semi evergreen, moist deciduous and mangrove forests comprising with diverse plants in each forest types (Bhuiyan et al., 2014; Hossain et al., 2019). Among these forest types, the evergreen and deciduous forests are mostly distributed in the hilly districts of
Bangladesh. The Chittagong Hill Tracts (CHT) in Bangladesh supports almost $80 \%$ of the country's total biodiversity (Hossain, 2016; Nishat and Biswas, 2005), and is inhibited by people from 12 ethnic groups (Rasul, 2007; Rasul and Thapa, 2006; Miah and Chowdhury, 2004; Chowdhury and Miah, 2003) who depend largely on forest resources to fulfill their livelihoods (Misbahuzzaman, 2015; Miah et al., 2012; Rasul and Karki, 2006; Rasul, 2007; Miah and Chowdhury, 2004).

Forests contribute a significant portion of the economy $(46 \%)$ at local and national levels, followed by crop/fruit production in the region (Rasul and Tripura, 2016; Ahammad and Stacey, 2016). From the beginning of forest management, Bandarban hill 
district of Bangladesh was designated for forest resources, particularly as a source of timber both from the natural forests and also from the plantations (Ahammad and Stacey, 2016; Hossain, 2016; Masozera and Alavalapati, 2004). But in course of time, most of the forestlands are becoming barren, covered with grass or with scattered trees, bamboos and weeds due to destruction of natural habitat of plants, over exploitation of natural green cover, conversion of large areas into non-forestlands, faulty management, jhum cultivation, invasion by exotics, land tenure ownership conflicts and so on (Akhtaruzzaman et al., 2016; Hossain, 2016). Traditionally, people have access to government forests in some cases yet their secure tenure rights have not yet been properly addressed (Barkat et al., 2010).

There have been many studies that have demonstrated the role of forest resources in strengthening the economic condition of forest dependent communities in both developed and developing countries of the of the world (Shackleton et al., 2008; Asfaw et al., 2013; Adam et al., 2013). However, very few studies were conducted to evaluate the socioeconomic factors that favour forest conservation along with influencing the livelihoods of forest dependent communities.
Therefore, we conduct the present study to explore the socio-economic factors that favour forest conservation and affect people's dependency on forest resources and livelihood in Bandarban hill district of Bangladesh.

\section{METHODOLOGY}

Socio-economic condition of the people of Bandarban hill district has been assessed through interview of the marginal dweller and Focused Group Discussion (FGD). Preliminary information about location, accessibility, communication means, and demography was collected from Conservator of Forest (CF) office of Bangladesh Forest Department (BFD), CHT Regional Council, different NGO's, literature and reconnaissance survey to the study area.

2.1 Description of the study area -The Chittagong Hill Tracts (CHTs) of Bangladesh is situated at the southeast region of the country $\left(21^{\circ} 25 \mathrm{~N}\right.$ to $23^{\circ} 45 \mathrm{~N}$ latitude and $91^{\circ} 54 \mathrm{E}$ to $92^{\circ} 50 \mathrm{E}$ longitude) and comprises three districts: Rangamati, Bandarban, and Khagrachari. This hilly forest region is traditionally resided by 12 ethnic groups, all with distinct cultures, languages, and traditions. We have selected two villages (Renikhayong para from Bandarban Sadar Upazila and Babu Para from Rowangchhari Upazila) under Bandarban district of Bangladesh (Fig 1).

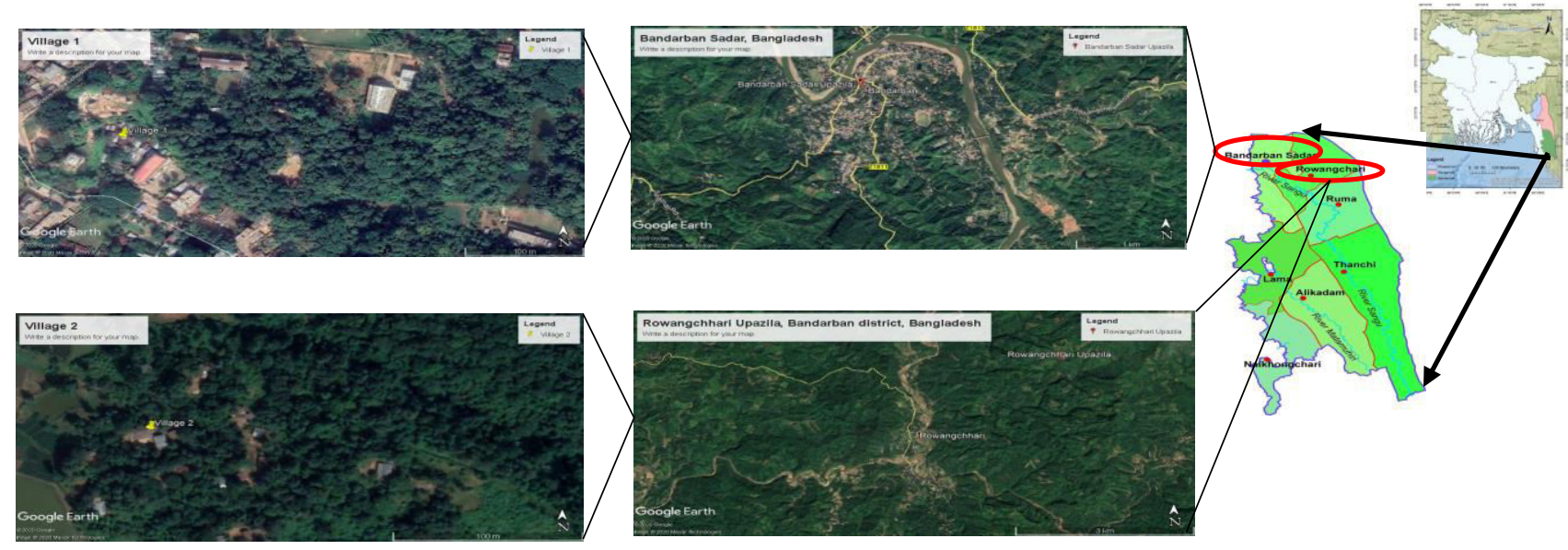

Fig 1: Location map of the study area.

2.2 Focus Group Discussion - Before starting for data collection from local people, a focused group discussion was conducted involving with the concerned NGO and Karbari. Karbari is the village head in each para that usually collects the tax from villagers and adjudicate disputes at village level and considered as the most powerful person in the village UniversePG I www.universepg.com social structure. Both male and female members participated actively in the FGD. We conduct 2 FGD from two villages (1 FGD for each village) to collect necessary information related to the forests and the dependency of local communities on forests from the view of several socio-economic factors. 
2.3 Interview of marginal stakeholder - A semistructured questionnaire was used for interview of the local stakeholders in order to conduct socioeconomic survey. The questionnaire was designed to explore socio-economic status of the local people. Detail data on forest resource extraction and corresponding monetary income was collected from 60 respondents (30 respondents from each village) to assess their forest dependency.

\subsection{Quantitative framework}

Logistic regression model: Generalized linear model (GLM), popularly known as logistic regression model was used in the present study to evaluate how people socioeconomic conditions affected their dependency on forest resources of CHT. GLM has been used in many socioeconomic studies. Mehta and Kellert (1998), Sah and Heinen (2001) and Holmes (2003) have used GLM to determine impacts of demographic and economic variables. Holmes (2003) has used logit model to identify the factors that determined people's forest dependency. Logistic regression has also been used by Ellis and Porter-Bolland (2008) to associate the socio economic reasons to deforestation in Mexico. However, generalized linear models (GLM) are made up of three components: Random, Systematic and Link Function. The random component identifies the dependent variable ( $\mathrm{Y}=0$ or 1$)$ and its probability distribution, the systematic component identifies the set of explanatory variables (Xi), and link function identifies a linear relationship between the explanatory variables and their probability function. That is,

$f(\operatorname{Pi}(\mathrm{Xi}))=\alpha+\beta \mathrm{iXi}$

Where, $\mathrm{Xi}$ is the vector of socioeconomic attributes of the respondents, $\mathrm{Pi}(\mathrm{Xi})$ indicates the probability of respondents' dependency on forest resources of CHT for their livelihoods (yes $=1$, otherwise $=0$ ) for a given value of $\mathrm{Xi}$ and $\beta \mathrm{i}$ is the vector of parameters to be estimated.

In generalized linear model, a logit link function can be defined as follows:

$f(\mathrm{Pi}(\mathrm{Xi}))=\log \left(\frac{\mathrm{Pi}(\mathrm{Xi})}{1-\mathrm{Pi}(\mathrm{Xi})}\right)$

Combination of equations (1) and (2) gives equation (3).

UniversePG I www.universepg.com
$\mathrm{Pi}(\mathrm{Xi})=\frac{e \alpha+\beta \mathrm{iXi}}{1+e \alpha+\beta \mathrm{iXi}}$

Now, if $\mathrm{Xi}$ is binary, equation (1) yields the following outcomes:

If $\mathrm{Xi}=1, \mathrm{f}(\mathrm{Pi}(1)==\alpha+\beta \mathrm{i}$ and if $\mathrm{Xi}=0, \mathrm{f}(\mathrm{Pi}(0)==\alpha$ Thus, $\beta \mathrm{i}=\mathrm{f}\left(\operatorname{Pi}(1)-\mathrm{f}\left(\operatorname{Pi}(0)=\log \frac{\frac{P i(1)}{1-P i(1)}}{\frac{1-P i(0)}{1-P i(0)}}\right) \ldots \ldots . .(4)\right.$

Where odds of $\mathrm{Xi},=1$ and $\mathrm{Xi}=0$ are defined respectively as, $\frac{P_{i}(1)}{1-P_{i}(1)}$ and $\frac{P_{i}(0)}{1-P_{i}(0)}$

The ratio of the two is called the odd ratio which represents the Odds that an outcome will occur (the probability of people's dependence on forest resources) given a particular exposure $(\mathrm{Xi}=1)$ compared to the odds of the outcome occurring in the absence $(\mathrm{Xi}=0)$ of that exposure. Thus,

Odd ratio $=\frac{\frac{\text { Pi (1) }}{1-\text { Pi (1) }}}{\frac{\text { Pi(0) }}{1-\text { Pi }(0)}}$

Equation (6) can be obtained by combining equations (4) and (5).

$\mathrm{Bi}=\log ($ Odd ratio $)$

So, Odds ratio $=\mathrm{e}^{\beta \mathrm{i}}$

Similar relationship can also be established if $\mathrm{Xi}$ is continuous.

Identification and definitions of variables: From focus group discussions and relevant literature explanatory variables have identified that might have leverage on the degree of people's dependency in the forest resources of Bandarban. To evaluate the factors affecting people's dependency in the forest resources of Bandarban, the dependent variable was Dependency. Dependency $=1$ if the percentage of total household income was $20 \%$ and above from the forest resources and 0 otherwise. The associated explanatory variables were Forest income, Education level, Family size, Age and Occupation. Forest income $=$ Forest income in thousand BDT, Education level = Number of schooling year, Family size = Number of family member per household, Age $=$ Age of respondents in year and Occupation $=1$ if respondents occupation is Jhum, 3 if Gardening (Practicing horticulture in the hills) and 2 otherwise (not related to forestry). 


\section{RESULTS AND DISCUSSION}

\subsection{Socio economic conditions of the respondents}

Demographic and educational status: The study revealed that on an average age of the respondents was $(39.75 \pm 3.59)$ years and illiteracy rate is about $56.3 \%$. Most of the respondent's education level is up to secondary level (Table 1).

Family size and income: The demography showed that on an average more than 6 people live in each family (calculated value $6.4 \pm 0.46$ individual) and monthly average income of the respondent is about (BDT 6,937.5 \pm 1374.26) in the study area (Table 2).

Occupation of the respondents: Jhum or shifting cultivation in the nearby hills is the major occupation of the respondents in Bandarban district. Jhum or shifting cultivation (Jhum cultivation is also known as the slash and burn agriculture, is the process of growing crops by first clearing the land of trees and vegetation and burning them thereafter) followed by mixed fruit gardening were the main occupations of the respondents of Bandarban. About $75.0 \%$ of the respondents are associated with Jhum and crop cultivation of that area. They cultivate various crops in the nearby occupied hills. The lands are kept fallow for one or two years after harvesting of the cultivated crops. Mixed fruit gardening appeared as a prominent sector for income generation since $19.0 \%$ people mentioned it as primary occupation (Table 3 ).

A small portion of the respondents $(6.0 \%)$ in this district is associated with non-forestry professions such as daily labor, teaching, engineer, business and service holder (Table 3).

Table 1: Demographic and educational status of the respondents.

\begin{tabular}{|c|c|c|c|c|c|c|}
\hline \multirow{2}{*}{$\begin{array}{c}\text { Name } \\
\text { (District) }\end{array}$} & \multirow{2}{*}{ Age (Years) } & \multicolumn{5}{|c|}{ Education level } \\
\cline { 3 - 7 } & & Illiterate (\%) & Primary (\%) & SSC (\%) & HSC (\%) & B.Sc. (\%) \\
\hline Bandarban & $39.75 \pm 3.59$ & 56.3 & 6.3 & 31.3 & 6.3 & 0.0 \\
\hline
\end{tabular}

Table 2: Family size and monthly average income of the respondents.

\begin{tabular}{|l|c|c|}
\hline Name & Family size (No./HH) & Monthly average income (BDT/HH) \\
\hline Bandarban & $6.4 \pm 0.46$ & $6,937.5 \pm 1374.26$ \\
\hline
\end{tabular}

Table 3: Primary occupation of the respondents

\begin{tabular}{|l|c|c|c|c|}
\hline Name & Jhum (\%) & Fruit gardening (\%) & Agriculture (\%) & Others (\%) \\
\hline Bandarban & 75.0 & 19.0 & 0.0 & 6.0 \\
\hline
\end{tabular}

Forests are the source of livelihoods for hundreds of millions of people worldwide especially in developing countries (FRA, 2010). Forest has always played a vital role in the economy of the indigenous people of CHT (Chowdhury et al., 2007; Rasul, 2007; Halim and Roy, 2006; Miah and Chowdhury, 2004; Chowdhury and Miah, 2003). Household fuel-wood, food, medicines, shelter building materials and agricultural implements are common uses of forest resources in Bangladesh (Jannat et al., 2018). Shackleton et al. (2007) mentioned that millions of South Africans derived direct benefits from forests and the contribution is approximately $20 \%$ of their livelihood. They also noted that forest resources are not a means of alleviating poverty for millions of people, but rather

UniversePG I www.universepg.com that they provide resilience in their livelihoods, thus preventing intensification of poverty. Bahuguna (2000) found the differences in rural communities' forest dependency in the Madhya Pradesh, Orissa, and Gujarat states of India which has similarities with the present study.

Kamanga et al. (2009) stated that the poorest segment depends more on forest than the least poor group. Miah et al. (2012) reported that degradation of forest resources are constantly associated with deepening poverty and livelihood vulnerability. Miah et al. (2012) found that dependence on the forest resources was influenced by easier forest access, the number of foragers from a household and family size. 


\subsection{Socioeconomic factors affecting people's forest dependency and livelihoods}

For the management and conservation of forest resources i.e. timber, fuel wood, Bamboo, Broom stick, medicinal plants, fish and other NTFPs (NonTimber Forest Products) of Bandarban hill district, it is important to address the needs of the people whose livelihoods are heavily dependent on the forest resources. Thus, one of the major aims of this study was to identify the major socioeconomic factors that governed people's degree of dependency on forest resources. Table 4 shows how the socioeconomic forces determined the local people's degree of dependency on forest resources. Of the six factors under consideration, Occupation, Forest income and Education level were found significantly contributing to a respondent's dependency on forest resources. The parameter estimate of Occu3 was 4.2438, which was significant at 5\% level (Table 4). The result indicates that respondent's forestry related occupation is positively aligned with their degree of dependency on the forest resources of Bandarban district. As expected this finding indicates that, the log (Odds) of forest dependency of a respondent with a forest related occupation (Gardening/Horticulture/plantations in the hills) was greater than that of a respondent with a non-forestry occupation by 4.2438 . Thus, we conclude that people were more likely to depend on forest resources if they worked in professions that required forest resources as inputs. Forest conservation is almost impossible without the support from the local community. Macura et al. (2011) reported that local people who had better access to forests, the forests were more aware of forest protection.

Table 4: Factors affecting people's dependency on forest resources

\begin{tabular}{|l|c|c|c|c|}
\hline \multicolumn{1}{|c|}{ Variables } & Estimate & Std. Error & Odds Ratio & z value \\
\hline (Intercept) & -4.7197 & 4.9704 & 0.0089 & -0.95 \\
\hline Age & -0.0495 & 0.1016 & 0.9517 & -0.487 \\
\hline Occu2 & 0.9346 & 1.9945 & 2.5462 & 0.469 \\
\hline Occu3 & 4.2438 & 2.0447 & 69.6721 & $2.076^{*}$ \\
\hline Education_level & -0.5523 & 0.2347 & 0.5756 & $-2.355^{*}$ \\
\hline Forest_income & 1.2297 & 0.4378 & 3.4202 & $2.809^{* *}$ \\
\hline Family_size & 0.7571 & 0.5004 & 2.1321 & 1.513 \\
\hline
\end{tabular}

* Significant at 5\% level and ** significant at $1 \%$ level ; Dependent Variable $=$ Forest Dependence $(1$ if dependent, 0 otherwise); Age $=$ Age of respondents (Years); Occu = Occupation (1 if Jhum or Agriculture; 2 if labour/ teacher/ business/ others (except forest related); 3 if Gardening/Horticulture/plantations in the Hills); Education_level = Education (No of schooling year); Forest_income $=$ Forest income (in thousand BDT); Family_size $=$ Family size $($ Number of family members).

Respondent's education level was inversely related to their degree of dependency on the forest resources. The parameter estimate of Education level was 0.5523, which was significant at $5 \%$ level. An increased year of schooling of a respondent decreased his log (Odds) by -0.5523 (Table 4). The reasons might be two firstly, an educated respondent might have better understanding about the importance of nature conservation and secondly, he might have managed to have a better and alternative income source elsewhere. This is an important finding in the sense that forest resources could be better managed if the forest dependent people could be educated. Similar findings were reported by Jannat et al. (2018) and Rahman et al. (2017) and Adhikari (2004) who mentioned that educated people are less dependent on forest resources.

\section{CONCLUSION}

People from developing countries like Bangladesh are directly or indirectly depend on forest resources for their daily needs. For this, it is important to evaluate identification of the driving factors that affect their livelihoods (Rabiul et al., 2020). We summarize that people's income, education and forest dependency are 
the major factors which significantly affect their perceptions and attitudes towards forest conservation and sustainable management. People should be motivated, focusing on the socio-environmental benefits from forest, to divert their negative attitudes towards forest conservation. Conclusively, we recommend that consideration of socio-economic factors of the local communities who are living around the forests is important for future policy formulation and decision making process towards sustainable management and conservation of forests in developing countries like Bangladesh.

\section{ACKNOWLEDGEMENT}

We are thankful to the Institute of Forestry and Environmental Sciences, University of Chittagong, Bangladesh for providing us in-kinds support during data collection from the fields during July 2016 to June 2017. We are also thankful to different government (Bangladesh Forest Department and CHT Regional Council) and non-government bodies who extended their hands to collect necessary secondary information for preparing this manuscript. Finally we would like to show our gratitude to the two anonymous reviewers for their valuable comments to make this manuscript publishable.

\section{COFLICTS OF INTEREST}

No potential conflict of interest was reported by the authors.

\section{REFERENCES}

1. Adhikari B, Salvatore DF and Lovett JC. (2004). Household characteristics and forest dependency: evidence from common property forest management in Nepal. Ecological economics, 48(2): 245-257.

https://doi.org/10.1016/j.ecolecon.2003.08.008

2. Adam YO and El-Tayeb AM. (2014). Forest dependency and its effect on conservation in Sudan: A case of Sarf-Saaid Reserved Forest in Gadarif state. Agriculture and Forestry, 60(3): 107-121.

https://www.cabdirect.org/cabdirect/abstract/201 $\underline{43356384}$

3. Asfaw A, Lemenih M, Kassa H, Ewnetu Z. (2013) Importance, determinants and gender dimensions of forest income in eastern UniversePG I www.universepg.com highlands of Ethiopia: The case of communities around Jelo Afromontane forest. Forest Policy and Economics, 28: 1-7. https://doi.org/10.1016/j.forpol.2013.01.005

4. Ahammad R, and Stacey N. (2016). "Forest and agrarian change in the Chittagong Hill Tracts region of Bangladesh.” In EL Deakin, M Ksatriya and TCH Sunderland (Eds.) Agrarian Change in Tropical Landscape, Bogo: Center for International Forests Research (CIFOR), pp. 190-233.

5. Akhtaruzzaman M, Osman KT and Haque, SMS. (2016). Some DTPA Extractable Micronutrients in Different Hill Forest Soils of Chittagong Region, Bangladesh. J. of Forest and Environmental Science, 32(1): 20-26. https://doi.org/10.7747/JFES.2016.32.1.20

6. Bahuguna VK. (2000). Forests in the economy of the rural poor: an estimation of the dependency level. AMBIO: A Journal of the Human Environment, 29(3):126-129.

https://doi.org/10.1579/0044-7447-29.3.126

7. Barkat A, Halim S, Osman A, and Ahsan M. (2010). Status and Dynamics of Land Rights, Land Use and Population in Chittagong Hill Tracts of Bangladesh. Human Development Research Centre, Dhaka, Pp. 300.

8. Bhuiyan MK, Hossain MK and Alam MS. (2014). Banspata (Podocarpus nerifolia, D. Don.)-A critically endangered tree species of Bangladesh. Institute of Forestry and Environmental Sciences, Chittagong, pp.72.

9. Chowdhury JA. (2004). Towards Better Forest Management. Oitijjhya, Dhaka, Bangladesh.

10. Chowdhury MSH, Halim MA, Miah MD, Muhammed N, Koike M. (2007). Biodiversity use through harvesting faunal resources from forests by the Mro tribe in the Chittagong Hill Tracts, Bangladesh. Int J Biodivers Sci Manag, 30:56-62.

https://doi.org/10.1080/17451590709618162

11. Chowdhury MSH and Miah MD. (2003). Housing pattern and food habit of the Mrotribe community in Bangladesh: A forest dependence perspective. Journal of Forestry Research, 14: 253-258. https://doi.org/10.1007/BF02856841 
12. Ellis E.A and Porter-Bolland L. (2008). Is community-based forest management more effective than protected areas? A comparison of land use/land cover change in two neighboring study areas of the Central Yucatan Peninsula, Mexico. Forest Ecology and Management, 256:1971-1983.

https://doi.org/10.1016/j.foreco.2008.07.036

13. Forestry Master Plan (FMP), (2016). Bangladesh Forest Department. http://www.bforest.gov.bd/

14. FRA, (2010). Global forest resources assessment 2010: Main report. FAO Forestry Paper 163. Rome: Food and Agriculture Organization of the United Nations.

15. Halim S, and Roy RD. (2006). Lessons learned from the application of human rightsbased approaches in the indigenous forestry sector in the Chittagong Hill Tracts, Bangladesh: A case study of the village common forest project implemented by Taungya.

http://hrbaportal.undg.org/resources/lessons-

learned-from-the-application-of-human-rightsbased-approaches-in-the-indigenous-forestry-

sector-in-the-chittagong-hill-tracts-

bangladesh-a-case

16. Holmes CM. (2003). The influence of protected area outreach on conservation attitudes and resource use patterns: a case study from western Tanzania. Oryx, 37: 305315.

https://doi.org/10.1017/S0030605303000565

17. Hossain MK. (2015). Silviculture of Plantation Tree Species of Bangladesh. Arannayk Foundation. Dhaka, Bangladesh, pp. 36.

18. Hossain MK. (2016). Re-greening the Degraded Hill Forests through Recovery and Restoration of Native Tree Species. National Tree Fair, Bangladesh Forest Department.

19. Hossain MK and Hoque ATRM. (2013). Eucalyptus Dilemma in Bangladesh, Institute of Forestry and Environmental Sciences, Chittagong, pp. 148.

20. Jannat M, Hossain MK, Uddin MM, Hossain MA and Kamruzzaman M. (2018). People's

UniversePG I www.universepg.com dependency on forest resources and contributions of forests to the livelihoods: a case study in Chittagong Hill Tracts (CHT) of Bangladesh. International J. of Sustainable Development \& World Ecology, 25(6):554561.

https://doi.org/10.1080/13504509.2018.1434571

21. Hossain SM, Sarker C, and Mahmud S. (2019). Effect of Plant Growth Regulator on the Growth and High Yield of Heat Tolerant Tomato Variety (Lycopersicon esculentum Mill). American J. of Pure and Applied Biosciences, 1(5), 30-43.

https://doi.org/10.34104/ajpab.019.0193043

22. Kamanga P, Vedeld P, Sjaastad E. (2009). Forest incomes and rural livelihoods in Chiradzulu District, Malawi. Ecological Economics, 68(3): 613-624.

https://doi.org/10.1016/j.ecolecon.2008.08.01 $\underline{8}$

23. Masozera MK and Alavalapati JR. (2004). Forest dependency and its implications for protected areas management: a case study from the Nyungwe Forest Reserve, Rwanda. Scandinavian J. of Forest Research, 19(S4), 85-92.

https://doi.org/10.1080/14004080410034164

24. Macura B, Zorondo RA, Grau FS, Demps M, Laval K, Garcia-Reyes, CAV. (2011). Local community attitudes toward forests outside protected areas in India. Impact of legal awareness, trust, and participation. Ecology and Society, 16(3): 10.

http://dx.doi.org/10.5751/ES-04242-160310

25. Miah MD and Chowdhury MSH. (2004). Traditional forest utilization practice by the Mro tribe in the Bandarban region, Bangladesh. Schweiz. Z. Forstwes, 155(3-4): $65-70$.

https://www.szf-jfs.org/doi/pdf/10.3188/szf. 2004.0065

26. Miah MD, Chakma S, Koike $M$ and Muhammed N. (2012). Contribution of forests to the livelihood of the Chakma community in the Chittagong Hill Tracts of Bangladesh. Journal of Forest Research, 17(6):449-57. https://doi.org/10.1007/s10310-011-0317-y 
27. Misbahuzzaman K and Smith-Hall C. (2015). Role of forest income in rural household livelihoods: The case of village common forest communities in the Chittagong Hill Tracts, Bangladesh. Small-Scale Forestry, 14: 315-330. https://doi.org/10.1007/s11842-015-9290-1

28. Nishat A and Biswas SR. (2005). CommunityBased Restoration of Degraded Tropical Hill Forests: Experiences from Krykhong Para, Chittagong Hill Tracts, Bangladesh. Bulletin of the National Institute of Ecology, 16: 1-11.

29. Rabiul Islam, Md Ekhlas Uddin, and Md. Firoz Alam, (2020). Isolation, identification and characteri-zation of Rhizobium species from soil of Cicer arietinum field of Faridpur in Bangladesh, International J. of Current Research, 12(4), 10322-10325. https://doi.org/10.24941/ijcr.38456.04.2020

30. Rahman MM, Mahmud MAA, Shahidullah M. (2017). Socioeconomics of biodiversity conservation in the protected areas: a case study in Bangladesh. International $J$. of Sustainable Development \& World Ecology, 24(1):65-72.

https://doi.org/10.1080/13504509.2016.1169453

31. Rahman MM, Guogang $\mathrm{Z}$ and Islam KS. (2010). A Review of the Present Threats to Tropical Moist Deciduous Sal (Shorea robust) Forest Ecosystem of Central Bangladesh. Conservation letter. Tropical Conservation Science, 3(1): 90-102.

https://doi.org/10.1177\%2F194008291000300 108

32. Rasul G. (2007). Political ecology of the degradation of forest commons in the Chittagong Hill Tracts of Bangladesh. Environmental Conservation, 34:153-163. https://doi.org/10.1017/S0376892907003888
33. Rasul G and Tripura NBK. (2016). Achieving the sustainable development in the Chittagong Hill Tracts Challenges and opportunities. ICIMOD Working Paper 2016/12. Kathmandu: ICIMOD.

34. Rasul G and Karki M. (2006). Political ecology of degradation of forest common in the Chittagong Hill Tracts of Bangladesh. The Eleventh Biennial Conference of the International Association for the Study of Common Property, Bali, 19-23 June.

35. Rasul G and Thapa GB. (2006). Financial and economic suitability of agroforestry as an alternative to shifting cultivation: The case of the Chittagong Hill Tracts, Bangladesh. Agricultural Systems, 91: 29-50.

https://doi.org/10.1016/j.agsy.2006.01.006

36. Sah JP, and Heinen JT. (2001). Wetland resource use and conservation attitudes among indigenous and migrant people in Ghodaghodi Lake area, Nepal. Environmental Conservation, 28:345-356.

https://www.ecologyandsociety.org/vol20/iss1 lart10/

37. Shackleton CM, Shackleton SE, Buiten E and Bird N. (2007). The importance of dry woodlands and forests in rural livelihoods and poverty alleviation in South Africa. Forest Policy and Economics, 9(5):558-577. https://doi.org/10.1016/j.forpol.2006.03.004

38. Shackleton SE, Campbell B, Lotz-Sisitka H and Shackleton CM. (2008) Links between the local trade in natural products, livelihoods and poverty alleviation in a semiarid region of South Africa. World Development, 36: 505526.

http://citeseerx.ist.psu.edu/viewdoc/download ?doi=10.1.1.534.9020\&rep=rep1\&type $=$ pdf

Citation: Jannat M, Hossain MK, and Uddin MM. (2020). Socioeconomic factors of forest dependency in developing countries: lessons learned from the Bandarban hill district of Bangladesh. Am. J. Pure Appl. Sci., 2(3), 77-84. https://doi.org/10.34104/ajpab.020.07@) @ 